\title{
Żale, sny i smutki - o poezji patriotycznej 1795 roku
}

\author{
Zofia Rejman
}




\title{
Zofia Rejman
}

\section{Żale, sny i smutki - o poezji patriotycznej 1795 roku}

\begin{abstract}
A ureli Drogoszewski rozpoczyna swe rozważania o poezji zarazporozbiorowej, a Władysław Włoch kończy książkę zatytułowaną Polska elegia patriotyczna w epoce rozbiorów przypomnieniem noweli dziewiętnastowiecznego poety i historyka literatury Konstantego Mariana Górskiego Biblioman. Bohater opowiadania, Leonard Sztremer, gorączkowo przetrząsa biblioteki szukając świadectwa rozpaczy, która opanować musiała Polaków po utracie niepodległości. Na próżno! Wśród dziesiątków szpargałów nie ma ani jednego wiersza, ani jednej linijki, w której zaświadczony zostałby dramat pierwszego pokolenia porozbiorowego, w którym brzmiałby ów wyższy, tragiczny ton. Wreszcie znalazł tomik, w którym były „żal i skarga i pogarda dla współczesnych i taki krzyk, taki hymn, jak gdyby ten człowiek wiedział, że mówi za całe przyszłe pokolenia" ". Zmęczony i szczęśliwy zasnął na chwilę, papiery zajęły się od dogasającej świecy i wymarzony tomik spłonął.

Nowela Górskiego, dająca świadectwo romantycznemu rozpoznaniu kultury porozbiorowej, wzbudza sprzeciw badaczy dowodzących, że przecież są Treny Morelowskiego, Emilka Woronicza, Smutki Niemcewicza i Kołłątaja, Bard polski Czartoryskiego, Żale nad grobem Zygmunta Augusta Karpińskiego i kilka wierszy anonimowych, wszystkie poświęcone lamentom nad utraconą ojczyzną. Jednakże nowela Górskiego ma jeszcze jeden aspekt: Leonard Sztremer nie szuka jakiegokolwiek tekstu; szuka dzieła, którego wielkość odpowiadałaby powadze chwili, szuka arcydzieła. Nie znajduje go, bo nie może znaleźć. Co do tego także
\end{abstract}

\footnotetext{
' K. M. Górski, Biblioman, Kraków 1896, s.25.
} 
badacze są zgodni - wszystkie wymienione przed chwilą wiersze są słabe i na wszelkie możliwe sposoby wtórne.

Jeżeli jednak warto przyjrzeć się wierszom z 1795 roku, to nie tylko po to, by podkreślić raz jeszcze silnie akcentowany, nowy w literaturze oświeceniowej ton goryczy, żałości i rozpaczy. Także dlatego, że poszukiwania autorów wierszy, zwrócone niemal w całości wstecz, ku wzorom akceptowanym i wypracowanym przez epokę staropolską, przynoszą kilka problemów ważnych dla całej literatury XIX wieku, stawianych niekiedy z zastanawiającą pasją i odwaga intelektualną, kilka lat później zatraconą niemal w całości. W tej perspektywie literatura zarazporozbiorowa stanowi dość czytelne podsumowanie repertuaru chwytów i wzorów wypracowanych dawniej w literaturze okolicznościowej i politycznej, a zarazem wskazuje, w pewnej mierze, kierunki poszukiwań dziewietnastowiecznej poezji polskiej.

Formą gatunkową, w której pierwsi poeci porozbiorowi zawarli swe refleksje i emocje, była elegia. I to nie tylko w sensie dosłownym - elegiami wypełnili swe zbiorki Kołłątaj i Niemcewicz, cyklem elegii nazywa Barda polskiego Wacław Borowy - ale i w znaczeniu szerszym, wytworzonym przez praktykę XVII wieku. Wówczas to elegia stała się bowiem kategorią ponadgatunkową, ów nowy rodzaj literacki - poezja elegijna - obejmował także treny, epitafia, lamenty i żale, a więc wszystkie analizowane teraz utwory ${ }^{2}$.

W swej pierwotnej wersji elegia złączona jest na stałe z imieniem Owidiusza, poety, który nie potrafił pogodzić się z wygnaniem, wciąż w napięciu oczekiwał zmiany losu i zmar1 w rozpaczy i osamotnieniu. W pięciu cyklach elegii Tristia i czterech księgach Listów z Pontu Owidiusz stale przywołuje na pamięć dawne, dobre czasy, opłakuje obecne nieszczęścia i wzywa zmiany losu, wprowadzając do tego gatunku dwuczęściową kompozycję, na która składają się dwie kontrastowe emocje: radosna przeszłość i dramatyczna, ponura teraźniejszość, której towarzyszy lęk przed niepewną przyszłością. Od Owidiusza wywodzi się także tradycja łączenia w elegii fragmentów lirycznych, w postaci biografii jednostkowej, a nawer autobiografii, z partiami epickimi zawierającymi historię polityczną narodu ${ }^{3}$. Wszystkie te elementy odnaleźć można w poezji 1795 roku, przy czym warto na chwilę zatrzymać się przy pierwszym z nich - owej idealizowanej, zamkniętej już przeszłości narodu.

To, że historia nie jest nam dana, nie stanowi katalogu faktów i dat, oświeceni rozumiel doskonale. Proces wydobywania ze starych kronik tych zdarzeń i postaci, które godne były chwały, rozpoczął Stanisław August, projektując Salę Rycerską Zamku Królewskiego w Warszawie. Skonstruowany przez niego panteon narodowych bohaterów w perspektywie okaza się bardzo trwały. W 1795 roku uległ jednak, na chwilę, wyraźnemu ograniczeniu. Sal Rycerskiej patronowało dwóch bohaterów: Jan Sobieski, król-wojownik, i Kazimierz Wielki król-budowniczy. Obok rycerzy, hetmanów i wodzów umieszczono tu portrety i biusty

\footnotetext{
2 Zob. Stounik literatury polskiego Oświecenia, red. T. Kostkiewiczowa, Wrocław 1991, hasło Elegia.

${ }^{3}$ Por. S. Stabryla, Owidiusz. Świat poetycki, Wrocław 1989.
} 
uczonych, filozofów i pisarzy. Zastanawia, jak szybko i jak dokładnie poeci porozbiorowi wyrzekają się pokojowych mitów i bohaterów akceptowanych przez polskie Oświecenie! Proces, który Teresa Kostkiewiczowa nazwała „sarmatyzacją historii”, dokonuje się tu w sposób totalny ${ }^{4}$. Dawna Polska jest krajem wojowników i rycerzy, przedmurzem chrześcijaństwa i obrończynią europejskiej wolności. Ukochany przedtem wzór, Kazimierz Wielki, pojawia się wśród dziesiątków przywoływanych postaci historycznych tylko raz — i to w bardzo ciekawej roli. Oto w ostatnim trenie Morelowskiego ożywają dawni bohaterowie, wszyscy z bronią w ręku, wśród nich

Łokietek mały z synem wielkim i w pokoju,

Kazimierzem, i wielkim, gdy potrzeba w boju,

Czynią swoje narady nad Brandenburczykiem,

Jak go mają na nowo zrobić hołdownikiem ${ }^{5}$.

Tak więc Kazimierz uczestniczy tu w naradzie wojennej! Z kolei Adam Jerzy Czartoryski przedstawia powstanie kościuszkowskie jako odwrócenie symbolicznego gestu przekuwania mieczy na lemiesze:

... Oracz spokojny

Z ofiarą swego życia staje w szyku zbrojny ${ }^{6}$.

Sarmacka przeszłość, która wypełnia elegie porozbiorowe, staje się wartością, z której naród może czerpać poczucie dumy, staje się gwarancją narodowej identyfikacji. Jeżeli ją mamy. Pojawił się bowiem jeden, mocny głos, iż zaborcy likwidując państwo polskie odebrali nam też historię:

Niestety! mamże wyznać straszne dla mnie słowo?

Krakusie i ty, Lechu, cnych Polaków głowo!

Gdy wasze dzieje wspomnę, oto wróg mi powie:

„Nie ma Polski, nie twoi oni są królowie,

Nie twoi są rycerze Czarniecki, Żółkiewski.

Polak jest dziś niepolski, Litwin nielitewski.

Miasto Lecha za przodka dziś Ruryka dostał,

Suworow twym Żółkicwskim i Czarnieckim zostal. (...)"7

\footnotetext{
+ T. Kostkiewiczowa, Horyzonty uryobraźni. O języku poezji czasów Ośniecenia, Warszawa 1984 (rozdz. 4: „Gdzie lud rzekl: chcę być wolnym". Glówne motyu'y stowne poezji patriotycznej).

${ }^{5}$ J. Morelowski, Wiersze, opr. E. Alcksandrowska, Wrocław 1983 (Zapomniani Poeci Oświecenia t. 2): Sen [w. 54-57]. Wszystkie cytaty z wierszy Morelowskiego pochodzą z tego wydania.

${ }^{6}$ A. J. Czartoryski, Bard polski 1795, opr. J. Kallenbach, Brody 1912 [w. 107-108]. Wszystkie cytaty pochodzą $z$ tego wydania.

7 J. Morelowski, Tren IV. Do dziejóu' polskich.
} 
Konsekwencją określenia się jako „bycie nikim”, „bycie znikąd” jest dramatyczny i kuriozalny plan samolikwidacji narodu, przedstawiony przez Morelowskiego w trenie VI Do matek polskich:

Przestańcie, matki polskie, dostarczać wrogowi

Niepotrzebnych już dzieci polskiemu krajowi! (...)

„(...) Nieszczęsne matki polskie! przebóg, nie Polaków,

Lecz wydacie nam Niemców, Moskalów, Prusaków. (...)

więc:

... gdy daléj Polakiem nie ma Polak słynąć,

Lepiej nam wszystkim w jednym pokoleniu zginąć. (...)"8

Jest to, jak mówiłam, głos odosobniony, interesujący przez swą skrajność, przez domyślenie do końca konsekwencji rozbiorów. Jest jednak także sygnałem, że historia, jej forma, istota i funkcja stanie się przedmiotem sporów, refleksji i rozmaitych, różniących się identyfikacji.

W refleksje o przeszłości i opisy dawnych zwycięstw wplatano, zgodnie z konwencją, partie liryczne. Najwyraźniej widać to na poziomie autobiografii - literackiego wykorzystywania własnych doświadczeń. Kołłątaj opatrzył swe Smutki następującym wstępem:

W tym dniu [10 X 1795] obchodziłem rocznicę owego wielkiego nieszczęścia, które przyniosła Polsce przegrana pod Maciejowicami (...). Trudno było opędzić się najsmutniejszym obrazom (...). Wziąłem do rąk pióro i pierwszy raz w moim więzieniu następujący wiersz napisalem $(\ldots)^{9}$.

O sobie i swej nieobecności w Polsce w czasie powstania myślał Czartoryski, gdy pytał:

Kto wie, gdyby ma cnota jej sprawę wzmocniła,

Możc jednym tchem dłużej ojczyzna by żyła.

Swoje lęki i niepokoje wyrażał ów zakładnik Katarzyny, gdy pisał:

By kawał ziemi nie był mi zabrany,

Za kawał kruszcu duch mój zaprzedany

Na przyszłość więzić (...)

\footnotetext{
${ }^{8}$ Tenże, Tren VI. Do matek polskich.

${ }^{9}$ H. Kołłątaj, Moje smutki podczas dlugiej niewoli w Josefstadzie. Smutek I. Dnia 10 października 1795, [w:] P. Żbikowski, Poezje więzienne Hugona Kotlq̨aja. Studia i teksty, Warszawa 1993. Wszystkie cytaty pochodzą z tego wydania.

${ }^{10}$ A. J. Czartoryski, Bard polski... [w. 340-342].
} 
Wreszcie ostatnie słowa poematu „Żegnamy ciebie, ziemio ulubiona..." poprzedzily rychły wyjazd księcia Adama Jerzego do Rosji.

Na nieco innym poziomie ujawniają się wątki autobiograficzne w Śnie Antka Pawęży Woronicza. Żale nad upadkiem ojczyzny zyskały tu charakter osobistego wyznania skierowanego do brata poety, a historia narodu została spleciona z dziejami rodu Woroniczów, niegdyś świetnego, później skarlałego i podupadłego. Zarysowana na końcu perspektywa nadziei dotyczy równocześnie domu rodzinnego i ojczyzny.

Ale i tam, gdzie poeci nie eksponują własnych doświadczeń, zaobserwować można proces indywidualizacji podmiotu lirycznego. Upraszczając można powiedzieć, że ten, który mówi, nie jest już kimś anonimowym, określonym wyłącznie przez słowa, które wypowiada. Nie jest też sentymentalnym człowiekiem prywatnym, o własnej, oryginalnej biografii. Eksponuje za to bardzo silnie poczucie wspólnoty ze wszystkimi, których boli i przeraża upadek ojczyzny. Czasem wiersz przybiera charakter intymnej rozmowy z konkretnym czytelnikiem-przyjacielem. Oto początek pierwszej elegii Niemcewicza:

Wśród żalu, którym wspólnie czujemy się zdjęci,

Jeśli me imię w twojej tkwi jeszcze pamięci,

Jeśli twe serce równą żalu przyjaźń dla mnie czuje,

Jeśli chcesz wiedzieć, w jakim miejscu się znajduję, (...)

Wiedz, że nad brzegami Newy jest miejsce tajemne

Oddalone od ludzi, zapadłe i ciemne

Tam (...) dni i miesiące

Wiodę nieszczęsny ${ }^{11}$.

Najczęściej poeci próbują opisać niedolę narodu opisując niedole idywidualnych bohaterów - Kościuszki i wodzów powstania 1794 roku zdradzonych i opuszczonych przez współtowarzyszy (Kołłątaj i Czartoryski). W Bardzie polskim są to wyznania dziewicy, młodzieńca i starca - postaci symbolicznych, rodem z Biblii, ale równocześnie posiadających bardzo konkretne, określone przez historię biografie. $\mathrm{Na}$ inny ciekawy aspekt tego zagadnienia zwróciła uwagę Teresa Kostkiewiczowa we wspomnianym opracowaniu ${ }^{12}$, pisząc, że w wierszach porozbiorowych każda refleksja ogólna jest natychmiast aktualizowana i konkretyzowana. Posłużyła się przykładem anonimowych Trenów upadku Polski, w których banalna dość refleksja o przemijaniu wszystkiego szybko przechodzi w skargę nad życiowym dramatem:

"J. U. Niemcewicz, Smutki... w więzieniu moskiewskim pisane do przyjaciela..., opr. L. Kamykowski, Lublin 1932: Elegia I. Wszystkie cytaty pochodzą z tego wydania.

12 Zob. wyżej, przyp. 4. 
Na cóż, człecze, krajesz ziemię,

Sadzisz drzewa, stawiasz domy,

By ciebie i twoje plemię

Pochłonął tyran łakomy?

A gdy cię znajdzie w obronie

I twych własności i pracy,

Twą śmiercią wieńczy swe skronie...

Wasz to jest obraz, Polacy! ${ }^{13}$

W ten sposób na różnych poziomach poezja porozbiorowa przygotowuje ukonstytuowany w literaturze XIX wieku typ bohatera, którego myślenie i działanie, którego biografię określa fakt bycia członkiem zniewolonego narodu.

Tak oto wychodząc od Owidiusza doszliśmy do kreacji narodowego bohatera.

Trzeba teraz powiedzieć, iż ma rację Piotr Żbikowski, który analizując Barda polskiego wskazywał, że zbiorek ten daleko wykracza poza poetykę elegii, zarówno w skali podejmowanych problemów, jak i w stosowanych technikach poetyckich ${ }^{14}$. To samo można powiedzieć o wszystkich wierszach z 1795 roku. W poetykach bowiem, od Scaligera do Brodzińskiego, akcentowano silnie związek elegii z poezją miłosną, decydowano, iż cechować ją powinna rzewność i łzawość, łagodność i słodycz, a nawet wdzięk. Tonacja omawianych wierszy jest zupełnie inna. Owidiusza jednak nie można pominąć. Wskazali na niego sami poeci porozbiorowi, świadczą o tym zaczerpnięte z rzymskiego poety motta, którymi opatrywali swe wiersze, a także ukazanie się niedługo później Owidego Nazona wierszy na wygnaniu pisanych... w tłumaczeniu Jacka Idziego Przybylskiego ${ }^{15}$. Druga uwaga jest istotniejsza. Oto Stownik literatury staropolskiej informuje, że w XVII wieku, w epoce baroku dokonało się w praktyce literackiej, poza poetyką, połączenie elegii i poezji okolicznościowej ${ }^{16}$. Powstała wówczas tzw. elegiosatyra, inaczej elegia polityczna. Tu właśnie ustalony został katalog wątków dominujących w poezji porozbiorowej — apologia rycerskiej przeszłości, kult bohaterów, wartość śmierci za ojczyznę, nienawiść do wrogów i zdrajców. Kiedy czyta się elegie patriotyczne okresu rozbiorów zebrane i wydane przez Władysława Włocha i Romana Kaletę, stanowiące bezpośrednią tradycję dla wierszy porozbiorowych, uderza wielka rozpiętość skali emocjonalnej — od żalu do rozpaczy, od lamentu do nienawiści, od rezygnacji po nadzieję, od uwielbienia dla bohaterów po jeremiaszowe przekleństwa rzucane na zdrajców ojczyzny. Retoryczność i apostroficzność charakterystyczna dla poezji politycznej oraz właściwy czystej

13 Treny upadku Polski, [w:] W. Włoch, Polska elegia patriotyczna epoki rozbiorów, Kraków 1916: Tren IV.

It P. Zbikowski, Kiedy rozpacz staje się rzeczywistościq. Uwvagi o poemacie A. J. Czartoryskiego "Bard polski”, „Pamiętnik Literacki” 1987 z.3.

is Owidego Nazona wiersze na uygnaniu pisane, to jest Rzeczy smutne, Klątua na Ibisa, Listy z Pontu, tł. J. I. Przybylski, Kraków 1802.

16 Slownik literatury staropolskiej, red. T. Michałowska, Wrocław 1990, hasło Elegia. 
elegii intymny, osobisty ton emocjonalny wspóltworzą charakterystyczny, niespokojny klimat poezji porozbiorowej. „Najdowałem jakąś przyjemność w rozbiorze tak boleśnych dla serca mego widoków” — napisze Kołłątaj ${ }^{17}$. „Widzieć te okolice gorzko nam i miło” — konstatuje znacznie bardziej mroczny bard Czartoryskiego ${ }^{18}$.

Ogólnie dominuje ponury ton. Autorzy wierszy z 1795 roku mają wyraźną świadomość nieodwracalności i ostateczności klęski. To krótki czas, zaledwie kilka miesięcy, najbardziej chyba dramatyczny czas w historii narodu. Do bitwy maciejowickiej pojawia się jeszcze w poezji nadzieja na zwycięstwo; napisane w kilka miesięcy później Zjawienie Emilki Woronicza wskazuje już na Napoleona i w nim widzi szansę na restytucję państwa. W 1795 roku nie było nic. Upadł naród, zginęła Polska, ojczyzna rozszarpana i wszystko stracone napisze Czartoryski. Ojczyzna ta zgonu dobiegła - to Kollątaj. I jeszcze: „Lecz Polsko! juz ciebie silne tyrany Na zawsze z kraju świata wymazały" ${ }^{19}$. Nawet topos Polska-Troja, który taką karierę zrobi na początku XIX wieku, pozbawiony jest nadziei na nowy Rzym, służy tylko zapisowi klęski:

$$
\begin{aligned}
& \text { Był naród, była Polska, byliśmy Polacy! } \\
& \text { Ta ojczyzna nabyta z długiej przodków pracy, } \\
& \text { Co rosła, co słynęłą przez wieków trzynaście, } \\
& \text { W jednym dniu z szczytu sławy spada na przepaście }{ }^{20} \text {. }
\end{aligned}
$$

Kiedy jednak przyglądamy się blizej znamionom owej klęski ostatecznej, zapisanej w wierszach 1795 roku, okazuje się, iż poeci nie szukali nowego języka dla opisu sytuacji, którą postrzegali jako zupelnie nową. Wołaniem: „Jeremijasza treny nucić by potrzeba, Zważając, jak na Polskę uwzięły się nieba” zaczynał anonimowy autor Treny nad upadkiem ojczyzny 1768 roku napisane ${ }^{21}$. I właśnie latwo czytelne tony Jeremiasza pobrzmiewają w analizowanych wierszach: „Gdzie rzuć, wszędy przekleństwa, płacz i narzekanie” — to Emilka Woronicza; „Płacz powszechny w stolicy na ulicach, rynkach” (Kołłątaj). Czasem klęska zamienia się w zagładę całkowitą:

Gdzie spojrzę, spustoszenie okropne i srogie Zżarło, co tylko ludziom na ziemi jest drogie, Po całym gruncie twoim drapieżność się wiła, Co żyje, rosnie, wszystko swym zębem zniszczyła,

\footnotetext{
${ }^{17}$ H. Kołłątaj, Elegia I.

${ }^{18}$ A. J. Czartoryski, Bard polski... [w. 125].

${ }_{19}$ Treny upadku Polski, Tren $V$.

${ }^{20} \mathrm{~J}$. Morelowski, Tren II.

${ }_{21}$ Treny nad upadkiem ojczyzny 1768 roku napisane, [w:] Literatura barska (Antologia), opr. J. Maciejewski, Wrocław 1976 (BN I 108).
} 
Trawie nie darowała! (...)

Pusto...2

Tę samą retorykę spustoszenia i klęski żywiołowej słychać w Trenach upadku Polski:

Tak więc najezdnik zaczął się nam sunąć

Jak czarny obłok, co wkrótce ma runąć,

A kędy tylko krok postawił mściwy,

Upadły domy, spustoszały niwy... 23

Zagładzie towarzyszy upokorzenie. Morelowski słyszy, jak nieszczęśliwemu narodowi „bez imienia i sławy urągają wrogi”. Upokorzenie zaś wywołuje przekleństwa. Morelowski przeklina tragiczny los, Czartoryski Katarzynę, Kołłątaj i anonimowy autor Trenów na upadek ojczyzny - zdrajców. Owe biblijne przekleństwa dopełniają opisu klęski, jaki zawierają wiersze z 1795 roku. Być może chęć przełamania tej wizji rzeczywistości, która wygląda jak spełnione proroctwo, sprawiła, iż autorzy chętnie odwołują się do poetyki snu, marzenia i wizji sennej. Na pewno nie może to być zjawisko przypadkowe, dotyczy bowiem większości analizowanych utworów. Sen Antka Paweży to tytuł wiersza Woronicza, Sen to ostatni tren Morelowskiego, Dziewicy z Barda polskiego zmarły kochanek pojawia się na granicy jawy i snu, śpi wreszcie Emilka, mała bohaterka sielanki Woronicza.

Sny od wieków zajmowały poetów i zawsze wydawały się im pełne znaczenia. Widziano w nich za Makrobiuszem „łaskawy lub nienawistny przejaw działania sił wyższych, demonicznych lub boskich” lub za Platonem wyraz „skrytego pragnienia” ${ }^{24}$. Sny odgrywały istotną rolę w Biblii i Eneidzie Wergilego, dwóch księgach ważnych dla poezji porozbiorowej. W obu wykorzystywane były po to, by przekazać pouczenie lub ostrzeżenie albo zapowiedzieć przyszłość. Miały więc charakter proroctwa. We śnie Bóg przekazał Abrahamowi objawienie (Rdz 5,12), śpiąca matka Eneasza usłyszała głos, zapowiadający zbudowanie Rzymu. Odwołanie się do poetyki snu sygnalizowało w wierszach porozbiorowych niechęć lub niemożność poprzestania na racjonalistycznym wyjaśnieniu porządku świata i konieczność odwołania się do praw wyższych, do myślenia religijnego. Ale — pisze Manfred Lurker — w kulturze chrześcijańskiej „przejście ze stanu pełnej świadomości w krainę marzeń sennych może być uważane za poważne zagrożenie, przynosi bowiem nieświadomość i całkowite uwikłanie się w sprawy tego świata"25. Przynosi chaos i prowadzić może do bluźnierstwa. Mroczny ton Smutków Kołlątaja i Niemcewicza, histeryczny klimat Emilki Woronicza, straszliwa wizja

22 A. J. Czartoryski, Bard polski... [w. 27-35].

${ }_{23}$ Treny upadku Polski, Tren II.

${ }^{24}$ Por. C. L. Lewis, Odrzicony obraz, tł. W. Ostrowski, Warszawa 1986.

${ }_{25}$ M. Lurker, Slownik obrazów i symboli biblijnych, tł. K. Romaniuk, Poznań 1989. 
okaleczonego kochanka z Barda polskiego, wreszcie groteskowe polskie „pola elizejskie” z trenów Morelowskiego korespondują w jakiś sposób z tym drugim znaczeniem snu.

Tym niemniej ważne jest także to, że autorom porozbiorowym nie wystarczaly rozważania polityczne, kiedy już zadali sobie pytanie o przyczyny upadku Polski. Dyskusja nad przyczynami klęski I Rzeczypospolitej trwała przez cały wiek XIX. Pierwsi poeci porozbiorowi wyznaczyli jej dwa podstawowe kierunki: z narodem omawiali przywary Polaków, Bogu przedstawiali niewinność.

Na tym pierwszym, racjonalnym poziomie przywolano cały niemal repertuar oskarżeń, jakimi wypełniona była poezja polityczna od XVI wieku. Najdobitniej zapisał je Kołłątaj:

Zginął naród przez płodu własnego poczwary, Gorszego nad się zrodził syna Adam stary. (...)

Ten zdradą kraju berło dla siebie zapewnił, Ten się z nieprzyjacioły ojczyzny spokrewnit, Ów, złota chciwy, własnych spółbraci zaprzedał I dla lichego zysku do rządu przyjść nie dał, Ów Moskwę naprowadził, ów kraj dzielił w Grodnie, Szarpał kościelną własność, kradł bratnią niegodnie, Posiadł urzędy kraju, poczciwym wydarte, Zlupił skarb, wskazał drogi do zbrodni otwarte. Wrócił nierząd i jawnie z cnoty się naśmiewał, Nie bał się grozy nieba, zemsty nie spodziewał ${ }^{26}$.

Cały dziesiąty tren Morelowskiego jest ilustracją przedstawionej w początkowych wersach tezy, iz

Zła niewola, zła wolność, gdy z niéj zły użytek, Skąd też naszą ojczyznę zgubił swobód zbytek.

Po czym autor dokładnie informuje, na czym owo nadużycie swobody polegało. Oto pacta conventa, które „na zgubę Polski jędza wściekła (...) przyniosła nam z piekła”. I „stan wyższy”, co "władze sobie przywłaszczył bez granic, / Pisał prawa na sejmach, a prawa miał za nic”. I bezmyślne pomiatanie stanem rolniczym. Także sejm, co „Sam uchwalał podatki, a nigdy nie płacił" ${ }^{27}$. Lista zarzutów jest długa i rozsądna, a zespół wad narodowych i błędów politycznych wystarczyłby do upadku państwa o wiele silniejszego od Polski. A przecież jest jeszcze zdrada. Kołłątaj miał obsesję zdrady, mówi o tym Piotr Żbikowski. Zdradził król i magnaci, przyjaciele i sojusznicy, generałowie i żołnierze. Ale także pozostali autorzy wszę-

\footnotetext{
${ }^{26} \mathrm{H}$. Kołłątaj, Elegia II.
}

${ }^{27} \mathrm{~J}$. Morelowski, $\operatorname{Tren} X$ 
dzie widzieli podstęp i przeniewierstwo, rzucali przekleństwa na króla, targowiczan, wiarołomnych dowódców, i byli pewni, że wskazują winnych klęski ojczyzny.

Ów pewny siebie ton tego, który wie i oskarża, w każdym tekście, gdzie się pojawia, jest natychmiast przełamywany. Punktem kulminacyjnym, powodującym zastąpienie rozważań publicystycznych dyskursem historiozoficznym, jest przypomnienie i opisanie Maciejowic i rzezi Pragi. W relacjach poetów nie są to przegrane bitwy, nie przegrana wojna nawet, ale zupełna zagłada, porównywana do klęski żywiołowej, przynoszącej mord i zniszczenie, ruiny i spalona ziemię. Szok wywołany brutalnością i okrucieństwem zwycięzców, poczucie całkowitej bezbronności ofiar spowodował, że pytanie o przyczyny klęski zastapiono pytaniem o sens zagłady.

Stanisław Tarnowski z kapitalną intuicją nazwał Barda polskiego Czartoryskiego „rozprawą między ludzkością a Bogiem”28. Taką właśnie „rozprawę” prowadzą wszyscy bez wyjątku autorzy wierszy z 1795 roku. Ton emocjonalny owego dyskursu jest bardzo zróżnicowany — przypomina bardziej gwałtowną rozmowę niż modlitwę. Ten bowiem, który pyta o sens klęski, nie zna odpowiedzi, ale zna ogólne zasady, niezmienne prawa rządzące polityką. Polityka jest tylko częścią historii, a historia świecka to tylko odbicie historii świętej. Bóg, do którego zwracają się Czartoryski, Niemcewicz, Kołłątaj, nie jest Tajemnicą, ale Opatrznością, jest gwarantem wiecznego ładu. Jest wielkim etykiem. Stąd błagania: wejrzyj na naszą niewinność lub chociaż zważ ciężar win -

A chociaż słusznie skarałeś za winy

Nas, od swych ojców mniéj cnotliwe syny,

Lecz czyliż nasze lepsze od nas wrogi?

Czyliz jest lepszy od nas Moskal srogi?

Albo nasz sługa, Krzyżak wiarołomny (...) $?^{29}$

Stąd prośba o interwencję: „Powstań, o Boże! karz wrogi złośliwe”. Albo:

Boże! gnębią cnotę zbrodnie,

Złamana Tobie przysięga,

Czas podnieść gniewu pochodnie,

Niechaj ogień zdrajców sięga,

Niechaj sie kają zuchwalce ${ }^{30}$.

Stąd prośba o litość: „może Boga Zastępów łzy niewinne wzruszą” - napisze Niemcewicz. Wszystkie te lamenty, prośby i narzekania wielokrotnie odzywały się w dawnej, staro-

\footnotetext{
${ }^{28}$ S. Tarnowski, Rozprawy i sprawozdania, Kraków1895, t. 1.

${ }^{29}$ J. Morelowski, Tren XIII. Do Boga.

${ }^{30}$ Treny upadku Polski, Tren $V$.
} 
polskiej literaturze przenikniętej prowidencjalną wiarą w Boską interwencję i sprawiedliwość historii. Trzeba od razu powiedzieć, iż takie myślenie dominuje w wierszach zarazporozbiorowych.

Pojawiają się jednak i głosy inne, jakby przychodzące z tej ciemnej strony snu. Głosy zwątpienia i bluźnierstwa.

Rozpocząć można od bardzo interesującej refleksji Kołłątaja. W drugiej elegii napisał: „Zginęła Polska... Zginęła! Lecz to skutek, ja szukam przyczyny”. I zaraz się reflektuje:

Ślepy! czemuż nie pomnę na prawdę tak dawną?

Tam przyczyna, gdzie rządy. Tam ją poznam kiedy,

Lecz nie w życiu śmiertelnym.

Nie znaczy to jednak, iż wyroki Pańskie są niepoznawalne. To tylko w Polsce, tym kraju „płaczu, biedy, / Skąd prawda uleciała, skąd wygnana cnota”, naturalna harmonia między Bogiem i człowiekiem uległa zakłóceniu:

Trzeba więc mężnie cierpieć, zawiesić badanie,

Czy widzim około nas śmiech, czy narzekanie,

Bo dopiero w ojczyźnie prawdy i nagrody

Najdziemy sprzecznych skutków przyczyny, dowody ${ }^{31}$.

Skargę na to, że rzeczywistość stała się zbyt trudna, niejasna i zagmatwana, kierują poeci nie bezpośrednio do Boga. Oskarżają okrutny los. Morelowski pyta:

Losie, kim jesteś i z czyjej to woli

Jednego sadzasz na wysokim tronie,

Gdy milijony w najsmutniejszej doli

Nieszczęsne do cię wyciągają dłonie? ${ }^{32}$

Dziewica skarży się w Bardzie polskim:

... Losie okrutny i niezrozumiały,

Dawco ty ślepy zawsze i szczęścia i chwały,

Kiedyż to klęski nasze wybiorą twe groty,

Zażarty na nas $z$ dawna... ${ }^{33}$

${ }^{31} \mathrm{H}$. Kołłątaj, Elegia II.

${ }^{32}$ Treny upadku Polski, Tren V.

${ }^{33}$ A. J. Czartoryski, Bard polski... [w. 133-136]. 
Badanie ślepych kolei losu prowadzić może do przejmującego poczucia całkowitego osamotnienia. Cóż robić, pyta Morelowski, „Gdy niebo, gdy świat cały opuścił niewinnych”? Prowadzić też może do utraty wiary:

$\mathrm{Na}$ toż tyle lat pobożnie przeżyłem,

Byś w końcu życia, o potworo sroga,

Przyczyną była, że nawet zwątpiłem

O rządzie prawej opatrzności Boga!... 34

Wyznanie Czartoryskiego, najbardziej dramatyczne, jedyne w poezji porozbiorowej, jest punktem kulminacyjnym sporu między Bogiem i narodem o prawo do ojczyzny.

Silne poczucie tragizmu losu podbitego narodu zaowocowało także w poezji 1795 roku zapisem przyszłych biografii Polaków, biografii, na które skazani będą przez następne sto lat. Kołłątaj i Niemcewicz są więźniami. Są, według naszej terminologii, więźniami politycznymi. Kołłątaj przedstawił też pierwszy chyba w naszej literaturze, ciekawy opis niedoli więziennego żywota:

Już rok minął, jak próżno nadzieja mnie łudzi,

Dzień przeszły równy temu, co mię ze snu budzi,

Jedna tylko choroba odmianę przynosi (...)

Zdrowie mię odstępuje, podagra się wzmaga,

Życie takie rzetelnym jest śmierci obrazem,

Pogrzebany w tych więzach, ledwie wiem, czy żyję (...)

Czy zasypiam wśród jęków, czy ze snu się budzę,

Tym się trapię, że czuję, tym się tylko nudzę ${ }^{35}$.

Czartoryski jest zakładnikiem. Wyjeżdża do Petersburga, by być gwarantem lojalności swojej rodziny. Ten sam Czartoryski zapisuje w Bardzie jeszcze dwie, dramatyczne decyzje: samobójstwo - zrozpaczony, skaczący do Wisły starzec to pierwszy samobójca w polskiej literaturze - i emigrację; Młodzieniec mówi:

Tam pójdę szukać śmierci, gdzie jej ogień czują,

Gdzie za nią stale walczą, gdzie Polski żałują ${ }^{36}$.

Lecz jeden tylko los jawi się w tej poezji jako koszmar — niewola. Naród niewolników — nie ma wiersza, w którym nie padałoby to określenie. Wiele się tu zmieniło. Jeszcze kilka lat temu Suchorzewski powiedział: że nie chce egzystencji Polski, nie chce egzystencji

${ }^{34}$ Tamże, w. 495-499.

${ }^{35} \mathrm{H}$. Kolłątaj, Elegia II.

${ }^{36}$ A. J. Czartoryski, Bard polski... 
imienia Polaka, jeżeli miałby być niewolnikiem króla. Nawet Tadeusz Czacki nie był pewien, czy wolałby być niewolnikiem obcego mocarstwa, czy Stanisława Augusta. Teraz niewola postrzegana jest jako koszmar. Poeci porozbiorowi natychmiast dostrzegli jej niszczącą i degenerującą siłę. Lapidarnie opisał to Czartoryski:

Spojrzeć na ucisk braci nie wolno ze łzami,

Wielbić gwałt u nich cnota, drżeć przed wyrokami,

Które mus i niecnota w swojej biją kuźni,

A gdy kto rozum, cnotę i ojczyznę zbluźni,

Podłym uśmiechem stwierdzić i jeszcze się łasić,

By nawet iskrę w sobie szlachetności zgasićc ${ }^{37}$.

Znowu najdramatyczniejsze konsekwencje niewoli dostrzegł i opisał Morelowski. Są nimi walki bratobójcze:

Cóż, gdy się między sobą wasze zwaśnią wrogi?

O, jaki waszych dzieci los napotka srogi!

Każą im w świętokradzkie iść sromotne wojny -

$Z$ jednéj i z drugiéj strony stanie Polak zbrojny.

Przyjaciel w przyjaciela swego piersi strzeli $(. . .)^{38}$.

A co w tym wszystkim mają robić poeci, gdzie jest ich miejsce i jaka rola? Wydaje się, iż jeden tylko autor, Adam Jerzy Czartoryski, podjął próbę stworzenia koncepcji poety nowego typu. Powołał on bowiem do życia polskiego barda. Być może był to świadomy akt, powtórzony za poetami niemieckimi. „U starożytnych Germanów bardów raczej nie było - pisze Maria Janion — ale w polowie XVIII wieku poeci (...) dopatrzyli się jednak obecności bardów u źródeł literatury niemieckiej i zapragnęli naśladować swoich poprzedników, czy też tworzyć w ich duchu" ${ }^{39}$. W Niemczech bard nabiera znaczenia, o jakim Macpherson nawet nie myślał, znaczenia wieszcza narodowego. Ale bard polski Czartoryskiego milczy, jest, żeby wrócić do słów Marii Janion, „milczącym świadkiem klęski”. Z milczeniem barda koresponduje symboliczny, powtórzony przez Karpińskiego, Niemcewicza, Morelowskiego gest odrzucenia lutni.

37 Tamże, w. 327-332.

${ }^{38}$ J. Morelowski, Tren VI. Do matek polskich.

${ }_{39}$ M. Janion, Projekt krytyki fantazmatycznej, Warszawa 1991. 